\title{
Physicochemical and biological treatability studies of urban solid waste leachate
}

\author{
${ }^{1 *}$ A. Torabian, ${ }^{2}$ A. H. Hassani and ${ }^{1}$ S. Moshirvaziri \\ ${ }^{l}$ Department of Environmental Engineering, Graduate School of the Environment, Tehran University, Tehran, Iran \\ ${ }^{2}$ Department of Environmental Engineering, Graduate School of the Environment, Islamic Azad University, Tehran, Iran
}

\begin{abstract}
In this research, physical, chemical and biological treatability of Tehran solid waste leachate was studied. Results indicate that the amount of COD for the fresh raw leachate of Tehran is equal to 66,608 $\mathrm{mg} / \mathrm{l}$. The leachate is transferred to an equalization tank for storage and $\mathrm{pH}$ control process. After neutralization, leachate is introduced to an up flow and down flow anaerobic reactor. The effluent of anaerobic reactor is conducted to a sequencing batch reactor. Sequence batch reactor (SBR) effluent was pumped in to sand and activated carbon filters, after chemical coagulation and clarification. Results showed that anaerobic reactor with detention time of 3 days had a 35\% COD removal and increasing the detention time to 4.5 days would improve the COD removal to $45 \%$. Nutrient adjustment with phosphorus and nitrogen increased the initial $23 \%$ efficiency of sequence batch reactor to $44 \%$. The effluent COD of SBR reactor was $21,309 \mathrm{mg} / \mathrm{l}$. Recycling of aerobic reactor effluent with incoming feed to anaerobic reactor reduced the anaerobic reactor influent COD to $20,000 \mathrm{mg} / \mathrm{l}$ and this caused $53 \%$ and $57 \%$ COD removal in the anaerobic and aerobic effluent, respectively. The total systems COD performance increased to $80 \%$ and SBR effluent COD eventually reduced to $4,000 \mathrm{mg} / \mathrm{l}$. Coagulation, flocculation and sedimentation processes were practiced to make the $4,000 \mathrm{mg} / \mathrm{l}$ effluent COD comply with environmental standards of Iran. The optimum coagulant found to be ferric chloride with the dosage of $50 \mathrm{mg} / \mathrm{l}$ at $\mathrm{pH}$ of 12 , which reduced $10 \%$ of COD to an amount of $3,676 \mathrm{mg} / \mathrm{l}$. The effluent was stored in a tank and then pumped in to pressure sand filter and afterwards to activated carbon filter. The COD removal was three and $90 \%$ for sand and activated carbon filters, respectively. The total process reduced the remaining COD to $36 \mathrm{mg} / \mathrm{l}$, which is in compliance with environmental standards of Iran.
\end{abstract}

Key words: Leachate, SBR, fixed bed, aerobic and anaerobic treatment

*Corresponding Author, E-mail: atorabi@chamran.ut.ac.ir

\section{Introduction}

City of Tehran with approximate population of 10 million people is producing daily amount of 6000 tons of solid waste. After being collected from the collection stationeries they were transferred by semi-trailers to the Kahrizak waste disposal site in South part of Tehran. Chemical and biological reactions would produce large solid waste leachate, which contaminates soil and groundwater in the area. It is therefore essential for this leachate to be properly treated. The other problem is that industrial solid wastes are not separated and therefore organic and mineral contents of Tehran leachate are extremely increasing and the COD in Tehran leachate is more than $60,000 \mathrm{mg} / \mathrm{l}$. It is to mention that quality and quantity of Tehran leachate is changing seasonally and in winter the leachate and its COD are low and would increase during the summer, which makes the treatment process harder. Nowadays, various leachate treatment processes are used in the world but probably it would be better to benefit from physical, chemical and biological processes simultaneously (Christensen, et al., 1997). Since different substances are included in the leachate various treatment processes are proposed. One of the methods is through anaerobic treatment using UASB and Fixed Bed. This process is being used in City of Istanbul in Turkey. The COD of leachate in the City changes from 6,820 in winter to 38,500 $\mathrm{mg} / \mathrm{l}$ during summer (Timur, et al., 2000). The other processes used are rotating biological contactor (RBC), (Hosomi, et al., 1991), activated sludge, SBR, (Henderson, et al., 1997). The combination of aerobic and anaerobic processes have shown good results in conducted research works but it is concluded that biological methods by 
themselves are not successful to completely treat the leachate and best results are obtained by combination of these methods with physical and chemical processes. Numerous physical and chemical processes have been introduced through out the world and among them membrane and gravel filtration for the physical and coagulation, flocculation and settling for the chemical methods are most popular (EPA, 1994).

\section{Materials and Methods}

The experiment was performed in Kahrizak solid waste land filling site, in Tehran on 20012002. In order to reach the objectives of the research; neutralization, aerobic and anaerobic reactors along with coagulation, flocculation and sedimentation tank, gravel filtration and activated carbon filters were provided. The neutralization tank with a volume of 180 liter was equipped with a mixer, $\mathrm{pH}$ controller and two dosing pumps for proper transfer of leachate to the anaerobic unit. The anaerobic rectangular cube had length of 1 meter, width of 0.4 meter and total height of 0.8 meter of which 0.1 meter was considered for sludge collection purposes and another 0.1 meter of that was considered as freeboard. The media were made of PVC with a volume of 100 liters The total volume of reactor was 320 liters but considering the volume of sludge deposition and the freeboard, the net volume was reduced to 180 liters. The area for media was assumed to be 25 square meters with area to volume ratio of 139. This reactor was consisted of an inlet and outlet valves with one drainage valve. Three baffles were predicted to regulate the up flow and down flow currents. The collection sludge zone was separated from the main part by a screen plate. Two aerobic reactors had used each length of 0.3 meter, width of 0.2 meter and height of 0.8 meter. They each work and load for 24 hours. All the valves used in this part were electrical and were controlled through a micro-system board. Two compressor machines (one as a reserve), with capacity of 150 liters in hour and having air pressure regulating valve were used for aeration. Two electrical floaters for managing the airflow to the reactors were also predicted. After the aeration process, its effluent entered the coagulation, flocculation and sedimentation tank and discharged to the environment after passing through the sand filtration and activated carbon filter. The $\mathrm{pH}$ of the flow was controlled by $\mathrm{NaOH}$, and after the neutralization, it entered the anaerobic reactor. The reactor was ready for operation after a month. The anaerobic reactor was examined in two cycles of 3 and 4.5 days and the aerobic reactor cycle of operation was in a period of 24 hours COD, turbidity, color, phosphorus, nitrate, nitrite and MLSS were measured at the inlet and outlet of each reactor in each period. All the procedures of this research work was conducted in temperature of 25 degrees centigrade and measurements of mentioned parameters were all conducted according to the methods introduced in APHA (APHA, 1995).

\section{Results}

The average concentrations from the anaerobic reactor after its stabilization in two months of operation are shown in Table1. The COD removal in three days detention time was approximately $35 \%$. The most and the least percentages of removal were related to nitrate and MLSS, being $47 \%$ and $10 \%$, respectively. The detention time of anaerobic reactor increased from three days to four and a half days after its two months operation. The SBR aerobic reactors were also put in operation. Table 2 shows the concentration of contaminants after two months of anaerobic reactor operation and SBR stabilization. With the increase of detention time of anaerobic reactor, the efficiency would increase from $35 \%$ to $44 \%$. The most and the least percentages of removal were related to phosphorus and MLSS, being 58\% and 12\%, respectively.

Table 1: Results of leachate treatment with detention time of three days

\begin{tabular}{|lccccccc|}
\hline \multicolumn{1}{|c}{ Parameter } & $\begin{array}{c}\text { COD } \\
(\mathrm{mg} / \mathrm{l})\end{array}$ & $\begin{array}{c}\text { Turbidity } \\
(\mathrm{FTU})\end{array}$ & $\begin{array}{c}\text { Color } \\
(\mathrm{Pt}-\mathrm{Co})\end{array}$ & $\begin{array}{c}\text { Phosphorus } \\
(\mathrm{mg} / \mathrm{l})\end{array}$ & $\begin{array}{c}\text { Nitrate } \\
(\mathrm{mg} / \mathrm{l})\end{array}$ & $\begin{array}{c}\text { Nitrite } \\
(\mathrm{mg} / \mathrm{l})\end{array}$ & MLSS \\
\hline Raw leachate & 66,608 & 3,935 & 18,525 & 205 & 285 & 1.53 & 30,877 \\
\hline $\begin{array}{l}\text { Effluent from the } \\
\text { anaerobic reactor }\end{array}$ & 43,627 & 2,802 & 14,119 & 130 & 150 & 0.95 & 27,848 \\
\hline Efficiency & $35 \%$ & $29 \%$ & $24 \%$ & $37 \%$ & $47 \%$ & $38 \%$ & $10 \%$ \\
\hline
\end{tabular}


Table 2: Average concentrations from the anaerobic reactor and SBR within two months of operation

\begin{tabular}{|lccccccc|}
\hline \multicolumn{1}{|c}{ Parameter } & $\begin{array}{c}\text { COD } \\
(\mathrm{mg} / \mathrm{l})\end{array}$ & $\begin{array}{c}\text { Turbidity } \\
(\mathrm{FTU})\end{array}$ & $\begin{array}{c}\text { Color } \\
(\mathrm{Pt}-\mathrm{Co})\end{array}$ & $\begin{array}{c}\text { Phosphorus } \\
(\mathrm{mg} / \mathrm{l})\end{array}$ & $\begin{array}{c}\text { Nitrate } \\
(\mathrm{mg} / \mathrm{l})\end{array}$ & $\begin{array}{c}\text { Nitrite } \\
(\mathrm{mg} / \mathrm{l})\end{array}$ & MLSS \\
\hline Raw leachate & 66,874 & 3,857 & 20,507 & 225 & 270 & 1.6 & 31,780 \\
\hline $\begin{array}{l}\text { Effluent from the } \\
\text { anaerobic reactor }\end{array}$ & 37,735 & 2,463 & 12,200 & 94 & 146 & 0.9 & 27,953 \\
\hline Efficiency & $44 \%$ & $36 \%$ & $41 \%$ & $58 \%$ & $46 \%$ & $44 \%$ & $12 \%$ \\
\hline $\begin{array}{l}\text { Effluent from } \\
\text { aerobic after } \\
\text { first month }\end{array}$ & 29,170 & 1,473 & 8,374 & 82 & 165 & 0.6 & 23,560 \\
\hline Efficiency & $23 \%$ & $40 \%$ & $31 \%$ & $13 \%$ & - & $33 \%$ & $16 \%$ \\
\hline $\begin{array}{l}\text { Effluent from } \\
\text { aerobic after } \\
\text { second month }\end{array}$ & 21,309 & 1,158 & 6,710 & 27 & 100 & 0.6 & 22,153 \\
\hline Efficiency & $44 \%$ & $53 \%$ & $45 \%$ & $71 \%$ & $32 \%$ & $33 \%$ & $21 \%$ \\
\hline
\end{tabular}

The efficiency of SBR aerobic reactor in the first month of operation was little and about $23 \%$. Artificial addition of nitrogen and phosphorus to system and balancing the ratio $\frac{C \times P}{N}$ increased the efficiency to $44 \%$. During the first month of operation of aerobic reactor and prior to phosphorus and nitrogen addition to the system, highest efficiency was related to turbidity with $40 \%$ removal and the least was related to nitrate. After the addition of nutrients these figures changed and the most and the least removals were related to phosphorus and MLSS, being $71 \%$ and $21 \%$, respectively.

Considering high COD in the raw leachate and that the influent in treatment plant was a combination of raw and old leachate, the COD concentration was stabilized to an amount of $35000 \mathrm{mg} / \mathrm{l}$. Table 3 shows the results of treatment in anaerobic reactor and SBR for the influent $35,000 \mathrm{mg} / \mathrm{l}$ after the dilution. The efficiency of both anaerobic and aerobic reactors increased only $1 \%$ and reached to $45 \%$. The most and the least removals in the anaerobic reactor were related to nutrients (phosphorus and nitrogen) and MLSS, being $50 \%$ and $26 \%$, respectively. These figures for aerobic reactor changed to $79 \%$ and $21 \%$ for phosphorus and MLSS, respectively.

The effluent COD from aerobic reactor has been approximately reported to be $10573 \mathrm{mg} / \mathrm{l}$. This concentration is relatively high to be discharged into the environment. Therefore in order to increase the efficiency of the system, effluent from aerobic reactor is returned to the neutralization unit in the beginning of the operation circuit. Table 4 shows the results after the effluent from the aerobic reactor is returned to the beginning of treatment plant. The concentration of influent to the anaerobic reactor after its circulation changed to 20,000 $\mathrm{mg} / \mathrm{l}$, therefore the efficiency increased. The efficiency of aerobic and anaerobic reactors increased respectively from $45 \%$ to $57 \%$ and $45 \%$ to $53 \%$. The highest and the least removals in the anaerobic reactor were related to COD and nitrate, being $53 \%$ and $26 \%$.

Table 3: Average concentrations obtained after the dilution of raw influent with old leachate

\begin{tabular}{|c|c|c|c|c|c|c|c|}
\hline Parameter & $\begin{array}{l}\text { COD } \\
(\mathrm{mg} / \mathrm{l})\end{array}$ & $\begin{array}{l}\text { Turbidity } \\
\text { (FTU) }\end{array}$ & $\begin{array}{l}\text { Color } \\
(\mathrm{Pt}-\mathrm{Co})\end{array}$ & $\begin{array}{l}\text { Phosphorus } \\
\text { (mg/l) }\end{array}$ & $\begin{array}{l}\text { Nitrate } \\
(\mathrm{mg} / \mathrm{l})\end{array}$ & $\begin{array}{l}\text { Nitrite } \\
(\mathrm{mg} / \mathrm{l})\end{array}$ & MLSS \\
\hline Raw leachate & 35,000 & 3,170 & 16,345 & 180 & 121 & 1 & 29,136 \\
\hline $\begin{array}{l}\text { Effluent from the } \\
\text { anaerobic reactor }\end{array}$ & 19,275 & 1,905 & 11,573 & 90 & 81 & 0.5 & 21,678 \\
\hline Efficiency & $45 \%$ & $40 \%$ & $30 \%$ & $50 \%$ & $33 \%$ & $50 \%$ & $26 \%$ \\
\hline $\begin{array}{l}\text { Effluent from } \\
\text { aerobic reactor }\end{array}$ & 10,573 & 897 & 5,787 & 19 & 57 & 0.35 & 17,132 \\
\hline Efficiency & $45 \%$ & $53 \%$ & $50 \%$ & $79 \%$ & $30 \%$ & $30 \%$ & $21 \%$ \\
\hline Total efficiency & $70 \%$ & $72 \%$ & $65 \%$ & $89 \%$ & $53 \%$ & $65 \%$ & $57 \%$ \\
\hline
\end{tabular}


Table 4: Average concentrations obtained after the circulation of treated leachate to the neutralization unit

\begin{tabular}{|lccccccc|}
\hline \multicolumn{1}{|c}{ Parameter } & $\begin{array}{c}\text { COD } \\
(\mathrm{mg} / \mathrm{l})\end{array}$ & $\begin{array}{c}\text { Turbidity } \\
(\mathrm{FTU})\end{array}$ & $\begin{array}{c}\text { Color } \\
(\mathrm{Pt}-\mathrm{Co})\end{array}$ & $\begin{array}{c}\text { Phosphorus } \\
(\mathrm{mg} / \mathrm{l})\end{array}$ & $\begin{array}{c}\text { Nitrate } \\
(\mathrm{mg} / \mathrm{l})\end{array}$ & $\begin{array}{c}\text { Nitrite } \\
(\mathrm{mg} / \mathrm{l})\end{array}$ & MLSS \\
\hline Raw leachate & 20,000 & 1,997 & 11,573 & 97 & 85 & 0.7 & 21,569 \\
\hline $\begin{array}{l}\text { Effluent from the } \\
\text { anaerobic reactor }\end{array}$ & 9,413 & 1,254 & 8,153 & 47 & 60 & 0.4 & 14,330 \\
\hline Efficiency & $53 \%$ & $37 \%$ & $30 \%$ & $52 \%$ & $29 \%$ & $43 \%$ & $34 \%$ \\
\hline $\begin{array}{l}\text { Effluent from } \\
\text { aerobic reactor }\end{array}$ & 4,043 & 627 & 3,575 & 10 & 35 & 0.2 & 7,140 \\
\hline Efficiency & $57 \%$ & $50 \%$ & $56 \%$ & $79 \%$ & $42 \%$ & $50 \%$ & $50 \%$ \\
\hline Total efficiency & $80 \%$ & $69 \%$ & $69 \%$ & $90 \%$ & $59 \%$ & $71 \%$ & $69 \%$ \\
\hline
\end{tabular}

Meanwhile, the most and the least removals in the aerobic reactor were related to phosphorus and nitrate, being $79 \%$ and $42 \%$. The total efficiency in the system for COD removal was close to $80 \%$ and the effluent COD concentration of the reactor reduced to $4000 \mathrm{mg} / \mathrm{l}$. The effluent was chemically treated by coagulant, flocculation and sedimentation after the biological treatment. The results of this treatment process are shown in Table 5.

As it is observed in the Table 5, the coagulation, flocculation and sedimentation processes did not seem to show high COD removal, but they had excellent performance in removal of color and turbidity. The coagulants used were alum, lime and ferric chloride, of which ferric chloride was determined to be the best coagulants. The best $\mathrm{pH}$ and suitable concentration were later discovered. The effluent entered to a storage tank and it is later pumped into gravel filtration and activated carbon tanks. Table 6 shows the effluent concentrations from the filters.

Table 5: Results of effluent leachate from chemical treatment process

\begin{tabular}{|lcccccccc|}
\hline Parameter & $\begin{array}{c}\text { COD } \\
(\mathrm{mg} / \mathrm{l})\end{array}$ & $\begin{array}{c}\text { Turbidity } \\
(\mathrm{FTU})\end{array}$ & $\begin{array}{c}\text { Color } \\
(\mathrm{Pt}-\mathrm{Co})\end{array}$ & $\begin{array}{c}\text { Phosphorus } \\
(\mathrm{mg} / \mathrm{l})\end{array}$ & $\begin{array}{c}\text { Nitrate } \\
(\mathrm{mg} / \mathrm{l})\end{array}$ & $\begin{array}{c}\text { Nitrite } \\
(\mathrm{mg} / \mathrm{l})\end{array}$ & $\begin{array}{c}\text { Sludge } \\
\mathrm{cc}\end{array}$ & $\begin{array}{c}\mathrm{FeCl3} \\
\mathrm{mg} / \mathrm{l}\end{array}$ \\
\hline $\begin{array}{l}\text { Effluent from } \\
\text { aerobic reactor }\end{array}$ & 4,043 & 627 & 3,575 & 10 & 35 & 0.2 & - & - \\
\hline After Jar test & 3,676 & 63 & 250 & 2 & 13.7 & 0.06 & 150 & 50 \\
\hline Efficiency & $10 \%$ & $90 \%$ & $93 \%$ & $80 \%$ & $61 \%$ & $70 \%$ & - & - \\
\hline
\end{tabular}

Table 6: Results of effluent from gravel filter and activated carbon filters

\begin{tabular}{|lcccc|}
\hline \multicolumn{1}{|c}{ Parameter } & $\begin{array}{c}\text { COD } \\
(\mathrm{mg} / \mathrm{l})\end{array}$ & $\begin{array}{c}\text { Turbidity } \\
(\mathrm{FTU})\end{array}$ & $\begin{array}{c}\text { Color } \\
(\mathrm{Pt}-\mathrm{Co})\end{array}$ & Phosphorus (mg/l) \\
\hline Influent to gravel filter & 3,676 & 63 & 250 & 2 \\
\hline Effluent from gravel filter & 3,569 & 53 & 232 & 1.94 \\
\hline Efficiency & $3 \%$ & $16 \%$ & $7 \%$ & $3 \%$ \\
\hline Effluent from first activated carbon filter & 357 & 9 & 46 & 0.4 \\
\hline Efficiency & $90 \%$ & $83 \%$ & $80 \%$ & $79 \%$ \\
\hline Effluent from second activated carbon filter & 36 & 3 & 6 & 0.1 \\
\hline Efficiency & $90 \%$ & $67 \%$ & $87 \%$ & $75 \%$ \\
\hline
\end{tabular}

Table 7: Efficiency of aerobic and anaerobic reactors in heavy metals removal

\begin{tabular}{|lcccccccc|}
\hline \multicolumn{1}{|c}{ Parameter } & $\mathrm{Cu}$ & $\mathrm{Zn}$ & $\mathrm{Cr}$ & $\mathrm{Cd}$ & $\mathrm{Pb}$ & $\mathrm{Fe}$ & $\mathrm{pH}$ \\
\hline Raw leachate & 0.34 & 5.665 & 1.12 & 0.17 & 1.5 & 41.88 & 6 \\
\hline After fixed bed & 0.039 & 0.501 & $\mathrm{Nd}$ & 0.1 & $\mathrm{Nd}$ & 9.12 & 7.1 \\
\hline Efficiency & $89 \%$ & $91 \%$ & $100 \%$ & $41 \%$ & $100 \%$ & $78 \%$ & - \\
\hline After SBR & 0.012 & 0.083 & $\mathrm{Nd}$ & 0.07 & $\mathrm{Nd}$ & 1.25 & 8.2 & - \\
\hline Efficiency & $69 \%$ & $83 \%$ & $100 \%$ & $30 \%$ & $100 \%$ & $86 \%$ & - \\
\hline Total efficiency & $97 \%$ & $99 \%$ & $100 \%$ & $59 \%$ & $100 \%$ & $97 \%$ & \\
\hline
\end{tabular}


As it is observed in the table, the efficiency of gravel filter was little, but activated carbon filters had reasonable removal rates that enabled the operators to discharge the effluent to the environment.

The other fact that investigated was related to the capability of heavy metal removal from the leachate through aerobic and anaerobic reactors. Table 7 shows the efficiencies of these two reactors in this regard. The removal rate for the chrome and lead in the anaerobic reactor was $100 \%$ and it also showed satisfying results for the rest of heavy metals.

The efficiency of aerobic reactor was also found to be satisfying in a way that all the metals concentrations reached to the discharging standards.

\section{Discussion and Conclusion}

The final results that were found out through the pilot research work could be concluded in the following notes.

- As the detention time increased from 3 days to 4.5 days, the efficiency of anaerobic reactor changed from $35 \% 44 \%$.

- The efficiency of aerobic system increased from $23 \%$ to $44 \%$ as the ratio $\frac{C \times P}{N}$ was adjusted.

- Even though raw leachate was mixed with the old leachate, the efficiency of the system did not changed considerably.

- The efficiencies of aerobic and anaerobic reactors both increased $12 \%$ and $8 \%$, respectively, with the circulation of treated leachate to the neutralization unit.

- The efficiency of both aerobic and anaerobic systems in heavy metal removal was great.

- In general, since the effluent leachate concentration was reported to be $4,000 \mathrm{mg} / \mathrm{l}$, it would be essential for complete treatment to use chemical and physical treatment processes.

- The chemical methods of coagulation, flocculation and sedimentation were not successful in COD removal although they proved to be perfectly reliable in removing turbidity and color.

- Existence of gravel filter after coagulation and sedimentation would not increase the efficiency although it decreases the suspended solids.

- The activated carbon filters are very effective in treating the effluent from biological treatment methods. They could remove almost $90 \%$ of COD that was not being removed in biological processes.

\section{References}

American Public Health Association (APHA), Standard methods for the examination of water and wastewater. $19^{\text {th. }}$ Ed., Washington D. C., 1995

Christensen, T. H., $R$. Cossu and $R$. Stegmarn, land filling of waste leachate, McGraw Hill Company, 1997

Environmental Protection Agency, Manual groundwater and leachate treatment systems, EPA/625/R-94/005, No. 625R94005, 1994

Henderson, J. P., D. A. Beslec, J. A. Atwater and D. S. Mavinic, Treatment of methanegenic landfill leachate to remove ammonia using a rotating biological contactor. J. Environ. Technol., 18 (7), 1997

Hosomi, M., I. Yuhei, K. Matsushinge and R. Sudo, Denitrification of landfilleachate by the modified rotating biological contactor (RBC), Water Science and Technology, 23: 1477-1485, 1991

Municipality of Tehran, Kahrizak leachate treatment studies. Organization of Waste Recycling and Composing, 2001

Timur, H., I. Ozturk, M. Altinbas, O. Arikan and B. S. Tuyluoglu, Anaerobic treatability of leachate: A comparative evaluation for three different reactor systems. Water science and Technology, 42 (1) \& (2): 287-292, 2001 
